be something quite different from what now passes as our political history. We could not have a better example of the intelligent combination and co-operation of scientific history and biography than is offered in Dr. Nathaniel Wright Stephenson's Nelson W. Aldrich, a Leader in American Politics. Here the skillful and sagacious use of unpublished materials reveals long-hidden secrets and makes plain many a hitherto obscure chapter in the politics of the last two decades of the ninetecnth century and the first two of the twentieth.

Mr. Aldrich, who represented Rhode Island in the United States Senate from 1883 to 1913 , was a statesman of recognized abilities whose fate it was to be distrusted by a large element of his own party. If that did not greatly disturb him in the days of his power, it was not, as was commonly thought, because he held a public-be-damned attitude, but rather because he honestly believed that the great public was an overgrown child truly unable to take care of itself without a guardian's watchful aid. Those who knew Theodore Rooscvelt only after he had left the White House may be more or less surprised by Dr. Stephenson's revelations of the long-continued intimacy between Roosevelt and Aldrich. Then, too, "the Four" in the Senate-Aldrich, Allison, Platt of Connecticut, and Spooner-formed a sort of bodyguard for Roosevelt in the early years of his administration, as this book shows. That wise old Connecticut Yankee, Orville H. Platt, was an impressive figure in those days, although the general public never knew him well. Allison of Iowa and Spooner of Wisconsin saw the clouds gathering in the West long before the storms of insurgency broke in the Republican party. All is clearly told in this admirable biography, which closes with an excellent account of Aldrich's part in laying the foundations of the Federal Reserve System in American banking.

Another good instance of history-making biography, occurring in a wholly different field, is .John Marsh, Pioneer, by George D. Lyman.

\title{
THE TESSON CLAIM IN LEE COUNTY AND THE EARLIEST ORCHARD IN IOWA
}

Tradition and fact have agreed on the earliest plantation of cultivated fruit trees in Iowa being near the present town of Montrose in Lee County. The confirmation by the United States government of the award by the Spanish lieutenant governor of the Tesson claim to the heirs of Thomas F. Riddick is of record in the litigation over the subject, but those details are not easily 
accessible in their authentic form. We publish them here with the view of making them casily available.

'The statement of David W. Kilbourne is reprinted with the same purpose. Countless similar statements are in print. Few if any contributors possessed as early and intimate associations with first settlements in Lee County as Mr. Kilbourne had. He was a permanent resident in Montrose in 1834 and one of its proprietors. He was first a merchant, later a capitalist and railroad builder. He was associated with or was the agent of strong financial men who contested with and won against the adversities Lee County presented to enterprise in its formative phases.

St Louis 20th March 1834. ${ }^{1}$

Sir

On the subject of the claim of Louis Honore (alias) Tesson to a league square of land at the head of the Rapids of the des Moines river I beg leave to refer you to the copies from the records of the Recorder of land titles herewith enclosed-From them it will be seen the facts in regard to the claims are shortly these-

On the 30th March 1799-a permission or warrant was given to Louis Honoré Tesson Trudeau then Lieut. Governor of upper Louisiana to settle and establish himself at that place which he accordingly did by building houses, inclosing land \& planting orchards and also cultivating the land \& residing on it for seven or eight consecutive years. In the concession or permission to settle, the Lieut. Governor states the object of the grantor part to be, that the grantee might carry on trade \& commerce with the Indians \& act as a superintendent over them keeping them faithfull \& obedient to the King of Spain-and that his conduct in that particular was such as to recommend him especially to the favor of the government.

No question is entertained of the genuineness of the permission to settle by Zenon Trudeau nor of the facts of inhabitation \& cultivation, according to the provisions of the laws of Congress, (see the evidence taken before $\&$ by Fredrick Bates Recorder of land titles the 18th of November 1813)-

Accordingly one mile Square was granted by Mr. Bates acting as Commissioner, provided the Indian title was extinguished-This Act of the Recorder is believed to be valid and confers an absolute right on the present claimants (the heirs of the late Col. T. F. Riddick my brother-in-law) for that quantity to wit 640 acres; and as such I always presumed it was ordered to be surveyed \& laid off by Mr. Sprigg, under

\footnotetext{
1The following letters and documents are from photostat copies of the originals now on fle in the Bureau of Indian Affairs, Washington, D. C. We have followed the style of spelling, capitalizing, etc., as used in the original documents.
} 
the belief that the government did not intend to appropriate private property for the use of the Indians. The chain of title is believed to be correctly given in the accompanying document from the Records-I believe the report of the Recorder, was made to Congress in November 1815, and his decisions in favor of claimants, approved \& confirmed by act of the 29th April 1816.-

In conclusion I will add, that I am persuided you yourself at the date of the treaty, reserving the lands in that neighborhood for the half breeds, must have known of the existence of this claim-inasmuch as I know as early as the year 1814 you were there \& no doubt saw the improvements-I can therefore scarcely believe it was the intention of the government in making \& sanctioning that treaty to deprive an individual citizen of his property-These facts I must beg of you sir to bring to the knowledge of the government, hoping that the legality \& justice of the claim will be recognized-

\section{With great respect Y Obed. Sev. \\ Will C. Carr}

\section{Louisville March 28, 1834.}

Sir,

Your letter of 5th February last, in relation to the Spanish grant of a mile square surveyed by Major Sprigg in the Sac \& Fox half breed reservation, was duly received.

Possessing no other information on this subject than is derivable from the enclosed documents, I address'd a note to Judge Carr, brother in law of the late Col: Riddick the claimant and refered him to the papers which had been placed in the hands of the Surveyor by the heirs of Riddick, his answer is herewith enclosed.

It is proper to state that I directed the surveyor to lay off the land in question-reflecting as I did that this act could invest the claimants with no additional title to the land, but might prevent much trouble hereafter, if their claim was good.

Hon: E. Herring Comm. Ind: Affs. Washington City.
I have the honor to be with great respect Your most ob. Serv Wm. Clark

\section{General Land Office} 12th April 1834

Sir:

I return the papers of the Heirs of T. F Riddick enclosed in your letter of the 9th Inst. and have to state that those papers correctly state that the claim in question was recommended for confirmation by the Recorder of Land Titles to the extent of 640 acres, if the Indian titlo was extinguished; but the Indian title not being extinguished in 1816, 
when the confirmatory law was passed, the claim in question is not now considered as confirmed; and further Legislative action is necessary before it can be recognized as confirmed by this office.

$\begin{array}{cc}\text { Hon Elbert Herring } & \text { Very respectfully } \\ \text { Commr of } & \text { Sir } \\ \text { Indian Affairs. } & \text { Your Obed Serv. } \\ \text { Elijah Haywood. }\end{array}$

Thomas F. Riddick assn. of Robidon of Tesson

To Fredrick Bates Esqre Recorder of land claims, Sir, Please to take notice that by virtue of the within Deed and papers hereunto annexed, I claim 7056 arpens of land situate on the River Mississipi District of St. Charles, and about 18 miles above River des moins. St. Louis Nov. 14th 1812-Thos. F. Riddick by his agt. M. P. Leduc.

Il est permis a Mr. Louis Honoré de s'établir au haut du Rapide de la rivière Des Moins et son etablissement formé il sera écrit a Mr le Gouverneur General Iui obtenir la concession d'un escape convenable pour faire valoir le dis établissement et en même temps la rendere utile au commerce du pelleteries en ce pays surveiller les sauvages et les contenir dans la fidelité qu'ils doivent a S.M. Sa conduite a cet égard devant lui servir de recommendation pour étre favorisé par le gouvernement de manière a lui rendre avantageux tout ce qu'il pourra faire d'utile a coopérer a l'aggrandissement da commerce dont il sera participant et a cet égard il lui sera permis de traitre avec tous les sauvages qui habitant sur cet rive du domaine de S.M. et de ne souffrir aucun autre traiteur en concurrence avec lui que ceux qui aurons des passeports signés de notre main

St. Louis, May 30, 1799-Tesson 'Trudeau.)

(Free translation.-It is permitted to Mr. Louis Honoré to establish himself at the head of the Rapids of the Des Moines River and this settlement made, $\mathrm{He}$ will write to Monsieur the Governor General to obtain a concession of the kind suitable to make the said settlement of value and at the same time useful to the commerce of the fur traders in the country and to watch over the savages and to hold them to the loyalty which they owe to S.M. [His Majesty]. His conduct in this regard should serve as a recommendation for him to be favored by the government in a manner to render advantageous to him all that which he shall be able to make useful in concurring in the enlargement of the commerce in which he will be participating and in this respect he will be permitted to negotiate with all the savages who live along this bank of the domain of S.M. and will allow no trader in competition with him unless they have passports signed by our hand.

St. Louis, May 30, 1799. Tesson Trudeau. 
St. Louis Nov. 18. 1813

(See statemt. on next page)

Thos. F. Riddick Ass. of Honore. Tesson \&c \&c Produces to wit \&c (See statement on top of next page) Cl. of 7056 arps. of Land on River Mississippi, dt of St. Charles about 18 miles above River Desmoins.Nicholas Boilvin duly sworn says that about 13 or 14 years ago he, witness was on this tract, when he saw Tesson in possession of the premises with his family inhabiting \& cult.g the same-He had a cabbin \& a small enclosure-He had also planted an orchard of fruit treesTesson permitted witness to erect a House on this Land, where he said witness Remained one year.-Tesson contd. on the land some years after, when as witness has been informed he sold to Robedeaux-A great number of bearing fruit trees is yet on this land. (Here follows the statement above referred to) (To wit-produces) a Permission to settle from 'I'esson Trudeau to Louis Honore, dated March 30th 1799,-order of C. D. Delasus Lt. Gov. dated 12th Mar. 1803. to sieze the property of Louis Tesson Honore, Jr. \& Cayhoe, to satisfy a debt due Joseph Robideau-Process verbal of seizure, dated 27 March 1803-Public sale of the property, purchased by Joseph Robidou (Copy cert.) dated 15 May 1803. Deed of sale from Augto. Chouteau Executor of last will of Robidou to Clt. dated 17th April 1810-Antoine Chemer duly sworn says that 15 or 16 years ago he witness saw Clt. Tesson inhabitating \& cut.g this trace-(knew Clt. as Louis Honore or 'Tesson, called either indifferently) - Witness knows that he contd. to inhabit \& cultivate this land during seven consecutive years- $-\mathrm{He}$ had orchard of fruit trees of about two arpens.-

\section{Recorder's Office,}

St. Louis Missouri Nov. 28th 1831.

I certify that the foregoing in part is truly Copied from Record Book F. page No. 125, (and the balance) to be truly extracted from pages No $73 \& 74$, of the minutes of the Recorder of Land Titles acting as Commissioner under the act of Congress entitled "An act making further provisions for settling the claims to Land in the Territory of Missouri" passed the 13th day June 1812-and other acts subsequently passed.- except those words underscored which are added to make sense.-

F. R. Conway

Recorder of Land Titles

in the state of Missouri 


\section{THOSE APPLE TREES}

(From the Iowa State Register, Feb. 24, 1864.)

I have been informed that some interest has been elicited on the part of the public, by the publication in the Register of two or three communications from different persons, relative to a number of apple trees still living on the Mississippi River a short distance below the town of Montrose (formerly Fort Des Moines) in Lee County. The place is called in that neighborhood the "old apple orchard." I have not had an opportunity to read either of the communications, and therefore cannot judge as to their truthfulness, or to what extent the writers may have drawn upon their imagination to cover the history of the trees in mystery.

Having lived near these trees (a part of the time in sight of them) for more than a quarter of a century, I can testify to the fact that the apple trees are there, and that they have not been barren cumberers of the ground, but have been as prolific from year to year as most of their species. I have often eaten of their fruit, and can bear testimony that it is very good. But the question that interests the public is, how came the trees there? What hand planted and protected them until they stood tall and strong like the forest trees with which they were intermingled and surrounded?

The spot they occupy, as well as all the surrounding country, was only a short time ago, comparatively, the home of Black Hawk and Keokuk, and their nations, the Sacs and Foxes.

I will here add that at the close of what is called the Black Hawk War barracks were erected at Fort Des Moines (now Montrose) for the accommodation of a regiment of United States dragoons. They occupied there till the spring of 1837 , when the post was abandoned, and the dragoons were stationed at the Raccoon Fork, which was immediately thereafter named Fort Des Moines. The same spring the name of the first Fort Des Moines was changed to Montrose.

A half-breed Indian of the Sac and Fox nation by the name of Red Bird (known among the whites as Thomas Abbot) had his wickeup contiguous to the spot where these trees are, as early as 1790 . He was often at Montrose in 1837-8-9. I knew him well. He was an intelligent and noble Indian. I have sat under these very trees with Red Bird and others of his nation, and have had from his own lips what I believe to be a reliable history of these identical trees. The first time I saw them my curiosity was excited, and I took no little pains to ascertain the facts in relation to them. Red Bird's story was confirmed by Black Hawk and other aged Indians of the tribe. It was the custom of these Indians to make at least annual pilgrimages to St. Louis to visit their good father, Gen. Clark, agent of Indian affairs, and to receive the supply of blankets, etc.

Now, somewhere between 1795 and 1798, Red Bird, then a young man, paid his annual visit to St. Louis in the early spring. On his return he 
stopped a few days at St. Charles, on the Missouri River, and when about to leave for home, a Nisheshin, Chemocoman (good white man) made him. a present of about twenty very petite young apple trees, put up in a bundle, with the roots protected, and instructed him how to plant them near his own wickeup. Red Bird brought them all the way in his hand, and. planted them promiscuously among the forest trees contiguous to his own home.

He protected them by placing stakes around them, and they grew up slim and tall, in consequence of being so much shaded.

I know it has been claimed or supposed by some, that Louis Honore Tesson, a Frenchman, planted these trees. He did stop awhile with Red Bird, fleeing from some epidemic that prevailed for a time in St. Louis, and afterward by representations made to the governor of Louisiana (then in possession of the French) that he had been of great service to their government among the Indians at this point, and claiming also that he had purchased of these Indians a league square of land-got a permit from the governor, as above, to enter, occupy and hold. In 1838 I held the legal possession of the mile square (which embraces Montrose and this orchard) when the heirs of Thomas F. Reddick, deceased, who was the assignee of 'lesson, commenced suit against me in an action of right for the possession-subsequently other parties defendant were substituted-which suit was finally decided in the Supreme Court of the United States in 1852.

But Red Bird and other Indians often told me that Tesson was a very poor man-that he lived while there around in the different wickeups-that they lodged and fed him-that he never furnished them with provisions as he claimed-that he never purchased an acre of land of the nation from those who lad authority to sell.

Red Bird said he was a che wal is ki-rascal. I am entirely satisfied of the truth of Red Bird's story. But I did not intend, when I commenced writing, to tax you with anything more than a brief account of the apple trees.

D. W. Kilbourne.

\section{HENRY W. WIILS}

The Ansals, as a policy, has devoted its biographical space almost exclusively to the persons in Iowa who have attained the public attention in some such place as membership in the General Assembly, in the District Court, in the military records, in the pulpit, in education, or in philanthropy.

We yield in this instance to a personal desire to record a line in memory of a co-worker for the state who served as none of these, but served under nearly all who have been conspicuous at 
Copyright of Annals of Iowa is the property of State of Iowa, by \& through the State Historical Society of Iowa and its content may not be copied or emailed to multiple sites or posted to a listserv without the copyright holder's express written permission. However, users may print, download, or email articles for individual use. 